\title{
Heracles's weariness and apotheosis in Classical Greek art
}

\section{Agotamiento físico y apoteosis de Heracles en el arte clásico griego}

Antonio Orlando Dourado Lopes

Universidad Federal de Minas Gerais, Brasil

douradolopes@letras.ufmg.br

\section{Resumen:}

Este estudio propone una interpretación general de las imágenes realizadas en Grecia, a partir del siglo V a. C. en monedas, joyas, pinturas de vasijas y esculturas, que muestran el agotamiento físico de Heracles y su apoteosis divina. Luego de una extendida consideración de los principales trabajos académicos que abordaron el tema desde finales del siglo XIX, procuro mostrar que la representación iconográfica del agotamiento de Heracles y de su apoteosis da testimonio de la influencia de nuevas concepciones religiosas y filosóficas en su mito, fundamentalmente del pitagorismo, del orfismo y de los cultos mistéricos, así como del fuerte intelectualismo de la Atenas del siglo $\mathrm{V}$ a. C. En lugar del destino de extremo esfuerzo y de los excesos característicos de sus representaciones literarias e iconográficas anteriores, el período clásico presenta a Heracles como un modelo de virtud y de dominio de sí, lo que simboliza la victoria del mérito sobre la persecución divina y las adversidades.

Palabras Clave: Heracles, Héroe, Apoteosis, Arte clásico griego.

\section{Abstract:}

In this paper, I propose a general interpretation of images showing the physical exhaustion and apotheosis of Heracles that were produced during the Classical period. These images appear on or take the form of coins, jewels, vase paintings, and sculptures. Building on the major scholarly work on the subject since the late $19^{\text {th }}$ century, I suggest that the iconography of Heracles shows the influence of new religious and philosophical conceptions of his myth, in particular relating to Pythagoreanism, Orphism, and mystery cults, as well as the intellectual climate of $5^{\text {th }}$ century Athens. Rather than appearing as an example of infinite toil and excess in the manner of earlier literary and iconographic representations, Heracles is presented in the Classical period as a model of virtue and self-restraint and a symbol of the triumph of merit over adversity and divine persecution.

KeYworDs: Heracles, Hero, Apotheosis, Classical Greek art.

\section{Symbolic aspects of the figure of Heracles in the context of $5^{\mathrm{TH}}$ Century GREEK BELIEFS}

In order to contextualize Heracles's iconography historically, I first consider narratives that describe his immortalization as a reward for his labors. In one well-known version, Heracles performs these labors under the oversight of his cousin Eurystheus, who rules over Mycenae and Tyrinth; in another, the labors are imposed on the hero by the Pythia of Delphi as a means of purification for killing his children in a fit of madness. In both cases, the labors are brought on by the harassment of Hera, who is infuriated by the fact that the hero is a product of her husband Zeus's love affair with the mortal Alcmene. ${ }^{1}$

The protracted evolution of representations of Heracles's exploits in the Archaic and Classical periods assimilated and established mythological, literary, and iconographic elements of Greek culture, some of which may have traced back to the Bronze Age. These elements are blended in the Homeric poems, each of which presents the hero's prowess in distinct ways. In general, the Iliad emphasizes the psychological and genealogical aspects of the heroes' destinies, often in a deterministic manner reminiscent of Athenian tragedy, whereas the Odyssey highlights individual effort and the suffering that is characteristic of the human condition. In both poems, diverse and intense pressures on human initiative enhance the psychological and theological significance of the characters' experiences through narratives about their acceptance of mortality. When considered together with the main Homeric heroes, Heracles, who belongs to an earlier generation, is conspicuous for his greater proximity to the gods, his greater exploits, and his greater suffering. At the same 
time, he remains comparable to the Homeric heroes in that his human dimension is almost always in the forefront. It is particularly telling in this respect that the Odyssey seems to associate Heracles with Odysseus by describing both heroes' exploits as aethloi. ${ }^{2}$

Adapting the epic tradition in his own way, Hesiod places 'painful Toil' (Ponos) as Eris' first-born in the Theogony, while stressing Zeus' and the other gods' capacity to endure the toil of their fierce fight against Tipheus. ${ }^{3}$ The importance of endurance is particularly highlighted in the Works and Days, which elevate the notion of 'work' to the rank of a moral value, condemning idleness (aergia) and proposing what can loosely be called an 'ethics of productive life' in contrast with the uncertainties of mortal destiny. ${ }^{4}$ Both the Homeric and the Hesiodic poems can thus be considered representative of an ancient epic tradition that praised human initiative and commitment, a moral perspective also emphasized by some archaic elegists. ${ }^{5}$

These preliminary remarks on the moral value of 'work', 'effort', and 'labor' in Greek archaic poetry provide a framework for understanding the evolution of Heracles in the arts, since the hero was conspicuously defined by toil and suffering from his earliest known representations. The advent and expansion of hero cults in Greece contributed further to his importance in Greek culture as a whole. According to Farnell, despite the absence of direct evidence in the Homeric poems, a few passages appear to refer to hero cults. ${ }^{6}$ Hesiod also alludes to this complex of religious practices but as usual adapts Greek religion to his rhetorical purposes, in particular when narrating the disappearance of the silver race from the surface of the earth: "But since the earth covered up this race too, they are called blessed mortals under the earth -in second place, but all the same honor attends upon these as well" (Works and Days, 140-142). ${ }^{7}$ The simple existence of hero cults in the Archaic period indicates that they had been active some time before, at least from the 12th century BCE on. Owing to his status as the most popular of Greek heroes, Heracles would very likely have been one of those "whose worship certainly belongs to the Homeric or preHomeric period, and who are generally supposed to have been in origin divinities that by the time of Homer had sunk into the position of mortal heroes or heroines". 8

These general remarks about Heracles's antiquity and nature provide historical context for the cultural process that transformed his characteristic violence against monsters and in war into a kind of moral virtue. ${ }^{9}$ The divine status typically emphasized in hero cult further strengthened his protective role. ${ }^{10}$ In poetry, a more restrained Heracles appears in Panyassis of Halicarnassus's Heracleia (frs. 19-22 West), in which, at least according to the interpretation of the editor, West, the hero, when encouraged by Eurythos, the king of Oichalia, to drink wine (fr. 19), reminds the latter of importance of self-restraint in such matters. This -in West's words- 'temperate Heracles' already represents a significant departure from earlier versions of him. ${ }^{11}$ In the context of the evolution in Greek spirituality from the $6^{\text {th }}$ century on, Heracles comes to represent universal conceptions of humanity as well as new ideals of sovereignty.

Near Eastern influence contemporaneous with the flourishing of Orphic-Pythagorean cults seems to have played a part in this evolutionary process, particularly in the spiritual manner in which Heracles's passage to immortality is represented. ${ }^{12}$ The religious atmosphere of Orphic-Pythagorean cults strongly connected Heracles to the mythological theme of a journey to the underworld. His association with the Eleusinian Mysteries in Attica is thus a natural progression manifesting his worshippers' interest in embedding him in their local culture, thereby creating the opportunity for other associations between him and Demeter. ${ }^{13}$ According to some interpretations, this new perspective on the Heracles myth motivated textual interpolations into the Homeric and the Hesiodic tradition, most notably his brief dialogue with Odysseus in the nekyia:

I recognized Heracles, strong and courageous - only his phantom, for he himself is among the immortal gods enjoying abundance, with Hebe of the beautiful ankles, 


\section{daughter of powerful Zeus and of Hera, whose sandals are golden. (Od. 11.601-604)}

I find convincing the arguments that lines 602-603 are an awkward and later, probably classical, addition that reflected then-current trends in the hero's myth, possibly contemporary with the appearance in Athenian vase painting of representations of the hero's apotheosis as a journey to the sky. ${ }^{15}$ Philological difficulties notwithstanding, the passage suggests that the interest in Heracles's apotheosis may well have interfered with the poem's processes of composition and transmission. Through strength and self-mastery, then, the 'hero of ponos' takes a step ahead of the other heroes that brings him closer to the gods. ${ }^{16}$

\section{The Classical period}

The moral dimension of toil and effort remains an important cultural trait throughout the Classical period, as is evident in a wide range of poetry and prose passages. In this climate, even the hedonistic god Dionysos was blamed for the toils (ponous) that he demands from his followers, as in the words of Silenus in the opening lines of the Euripidean satyr play The Cyclops: "O Dionysus, do you know how many times -not only now / but since I was a youth-I put myself through toils for you? So many times they're numberless”. ${ }^{17}$

Always very popular in literature and the arts, Heracles's representation as a suffering hero is transformed by his acceptance in Olympus, in which respect his destiny is comparable to that which Proteus predicts for Menelaus in the Odyssey. ${ }^{18}$ Beginning in the $5^{\text {th }}$ century BCE, Athenian vase painters, inspired by this second life of his myth, multiplied the representations of Heracles's apotheosis to the point that it became the most common form of his iconography. ${ }^{19}$ Instead of the magnificence of diverse superhuman exploits that challenge death, Athenian iconography comes to prefer immobile heroes, in this respect synthesizing new Greek values associated with the intellectual and political climate of the $5^{\text {th }}$ century BCE. ${ }^{20}$ Heracles in this later context becomes a figure of calm, an exemplar of excellence (aretē) and law (nomos).

The so-called 'Choice of Heracles' is arguably the most programmatic literary evidence of this perspectival shift in the hero's myth. Originally conceived as a rhetorical discourse by the $5^{\text {th }}$ century sophist Prodicus and now lost, it is known from accounts in Xenophon and Diogenes Laertius. ${ }^{21}$ In a scene related by these authors, Socrates cites the Choice in the context of a discussion of enkrateia, that is, self-control regarding pleasures in general (eating, drinking, enduring extreme weather and toil) and sexual behavior in particular. $^{22}$ Beginning with a statement of the importance of enkrateia in political activity, both for the rulers and the ruled, Socrates develops the traditional argument that he who governs others must first and foremost be able to govern himself, comparing life to a road chosen by each person, either of indiscipline and excessive pleasure or of measure and temperance. Socrates' questioning emphasizes the necessity that a

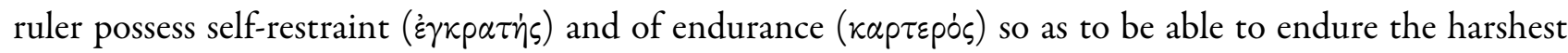
deprivation, and the strongest temptation, without neglecting his commitment to his city.

In Xenophon's account, Socrates cites Prodicus as his source for the story of how a hesitant or perplexed (aporounta) young Heracles is approached by two women, each of them suggesting that he should follow a different road. The first is naturally beautiful, whereas the second is artificially and exaggeratedly adorned and overtly proud. ${ }^{23}$ As the first woman is preparing to address Heracles, the second, outpacing her (phthanon) rushes up to tempt him with an easy, effortless road:

I see, Heracles, that you are perplexed as to which road you should take in life [aporounta poion hodon epi ton bion trapeì]. If you befriend me, I will lead you to the most pleasant and easiest road; you will not miss the taste of any delight, and you will live your life without experience of the hard things. ${ }^{24}$ 
Prompted by Heracles, the same woman introduces herself by saying: "My friends call me Happiness [Eudaimonia] (...) but those who hate me nickname me Vice [Kakia]". The second woman, who does not introduce herself but is called by Socrates Virtue (Aretē), proposes for Heracles an alternative and very different road:

I too have come to you, Heracles, since I know those who begot you and that nature of yours, having observed it in your education. Therefore, I have hope: for you, that if you should take the road toward me, you will become an exceedingly good worker of what is noble and august; and, for me, that I will appear still far more honored and more distinguished for good things. I shall not deceive you with preludes about pleasure. But I shall truthfully describe the disposition the gods have made of the things that are. For without labor and attentiveness the gods give humans none of the things that are good and noble. But if you wish the gods to be gracious to you, you must serve the gods; if you want to be cherished by your friends you must do good deeds for your friends; if you desire to be honored by some city, you must benefit the city; if you think you deserve to be admired by all Greece for your virtue you must attempt to be the cause of good for Greece; if you wish the earth to bear you fruit in abundance, you must serve the earth; if you think you must become rich from cattle, you must be attentive to the cattle; if you set out to increase yourself through war and wish to be able to make your friends free and subdue your enemies, you must learn the warlike arts themselves from those who understand them, as well as practice how one must use them. And if you wish to be powerful also in your body, you must accustom your body to serve your judgment, and you must train with labors and sweat. ${ }^{25}$

By invoking the general principle that no achievement can be attained without persistent effort, the second woman implies that the first woman's effortless pleasures cannot possibly be enjoyed by a mortal. In addition and more importantly, the second woman brings the gods into the discussion, making a point of stating that effort is indispensable even to those mortals who receive their favor:

But I am a companion of the gods, and a companion of good human beings. No noble work, divine or human, comes into being without me. I am honored most of all among gods and among those human beings by whom it is fitting to be honored; for I am a cherished coworker for artisans, a trusted guardian for masters of households, a well-disposed assistant for household servants, a good helper for the labors of peace, a reliable ally for the works of war, and an excellent partner in friendship. ${ }^{26}$

While the choice that these women present is binary, taking the form of two roads, their offers are not symmetrical; for while Vice promises a road leading to happiness, that is to say, to herself (according to what she wants Heracles to believe), Virtue does not even mention happiness or any form of bodily pleasure, proclaiming as her main advantages her indispensable participation in any good work (ergon), both human and divine, the company of gods and good men, and the privilege of being honored by them.

Scholars have linked this parable to earlier Greek narratives in which a hero meets a group of women and thereupon makes an important decision regarding the course of his life. According to Burkert, the fundamental shift in the characterization of Heracles through which he became a culture hero served as a powerful metaphor in the evolution of Greek classical thought. ${ }^{27}$ Together with Odysseus, Heracles represented the definitive traditional model of triumph over the inevitable challenges that humans face. ${ }^{28}$ Both embedded in this wide process and influencing it, the cycle of Heracles's labors and exploits must also be considered in the context of a drive for increasing clarity in the Greek iconographic vocabulary. The many changes in the expression of heroic action were naturally reflected in images of heroes. ${ }^{29}$ Only when Heracles had transcended the limits already established for the representation of human action did he appear as the immortalized hero living among the gods. ${ }^{30}$ At this point, the confrontations with monsters and disasters, battles of the sexes, and rivalries with the gods gave way to representations of Herakles's physical exhaustion, which manifested the very exhaustion of his mortal possibilities. ${ }^{31}$

On the other hand, there is also reason to suspect Near Eastern influence in the spiritual manner in which Heracles's passage to immortality is represented. ${ }^{32}$ According to Mühl, possible Near Eastern models include the Adapa, Etana, and other Old Babylonian-Sumerian legends and, in the Old Testament, the prophets 
Enoch and Elisha (Genesis 5.24); looking beyond the Near East, he cites the Indic Veda (Atharva Veda XVIII, 4.10) and, in the Mahabharata, Bhisma. ${ }^{33}$

\section{Physical weariness in some Classical images}

The changes in Heracles's representation from the $6^{\text {th }}$ through the $4^{\text {th }}$ centuries BCE took place in the context of more widespread change in the representation of heroes on Athenian vases. ${ }^{34}$ As noted long ago by Furtwängler, these changes would first have occurred in images on smaller and less prestigious objects, most notably coins, before manifesting in sculpture. ${ }^{35}$ Instructive in this context is an Etruscan scarab of the Severe Style, dating to the $4^{\text {th }}$ century, that displays "Heracles unbearded (according to the Italic usage), tired, with his head leaning on his right hand; in front of him a fountain that will refresh him flows from the rocks". ${ }^{36}$ So also a sumptuously decorated coin from Abdera which "displays the hero unbearded, tired and resting; his stance, particularly that of the head, has both something of weariness and of sadness". ${ }^{37}$ Granted that these two examples are on coins, on which artists' expressive resources were fairly limited, the head position can be considered the decisive element for the overall interpretation of weariness. In fact, this shift in the head position to express weariness and suffering is the most prominent change witnessed in numismatic iconography during the $5^{\text {th }}$ century BCE. ${ }^{38}$

Another important example of Heracles's connection with the afterlife can be found on one of the metopes of Zeus's temple in Olympia, sculpted between 470 and 457 BCE, which provides the earliest example of the dodekathlos. ${ }^{39}$ The relevant metope here is only fragmentary, but it seems to show Heracles in the process of recovering from a recent effort. One of the difficulties of interpreting this image is the novel way in which the labor involving the Nemean lion is represented: earlier representations focused on the combat between the hero and the lion, ${ }^{40}$ but the metope depicts the moment immediately afterward. Thus Heracles inclines his head toward the floor and rests it on his right hand while resting his right arm on his right leg, which in turn rests on the animal's carcass; Athena and Hermes observe the scene from behind and to the right, respectively. ${ }^{41}$ As with the $5^{\text {th }}$ century coins mentioned above, the position of the hero's head provides the narrative cue for interpreting the image despite its fragmentary state.

To be more specific, the first reconstruction of this metope presented the hero's head turned to the left, which gave him a contemplative look. In the new reconstruction, he looks directly at the ground, thereby expressing physical weariness rather than a more psychological disposition, such as fear or sadness. Regarding the connection between this labor and the afterlife, Kerényi makes the important point that this sculptural group does not foreshadow the hero's future suffering, as had formerly been proposed ${ }^{42}$-rather, the representation of a body suffering in anticipation would correspond to the Christian conception of an incarnated Christ, to a 'history in flesh' (en sarki) tracing back to the Jewish prophetic tradition. ${ }^{43}$ Basing his interpretation instead on scholia to Virgil's Georgics attributed to the grammarian Probus and on passages in Pseudo-Apollodorus' Library, Kerényi argues that the myth about the Nemean lion presupposes a number of elements related to the underworld:

(a) descent to Hades to hunt the lion and deliver its carcass to Molorchus, a Nemean hero;

(b) a thirty-day deadline requested by Heracles himself, during which Molorchus grants him access to the underworld in order to accomplish the task and after which Molorchus is to grant Heracles divine honors;

(c) an irresistible sleep - perhaps sent by Hera- overtakes the hero after he kills the lion but is still in the underworld and threatens to trap him there;

(d) once Heracles awakens, he races to reach the exit in time. ${ }^{44}$

From this perspective, the sculptural group on the metope seems to represent the exact moment when the hero emerges of the cave through which he originally entered the underworld, victorious but exhausted by 
the effort that he has just expended. Alternatively, the scene could depict the precise moment in which he struggles with sleep while he is still in the underworld and at risk of being unable to escape. ${ }^{45}$

Hermes's presence, as the psykhopompos who regularly travels between the earth and the underworld, supports Kerényi's interpretation, though, curiously enough, he makes no mention of the god. ${ }^{46}$ In any case, with or without Hermes, the metope is remarkable in portraying an invincible hero's solitary struggle. Beyond the significance of the mythological information uncovered by Kerényi's perceptive study, the difficulty of interpreting this sculptural group is further increased by the subtlety of the artistic language used to convey the invisible struggle within the limits of the body. ${ }^{47}$

Another classical representation of Heracles that has proved difficult to interpret is his apotheosis in Athenian pottery. The popularity of this image was directly related to the broad diffusion of the hero's cult in Attica. ${ }^{48}$ Built up from the borrowed iconographic patterns of 'parade' or 'quadriga' but also incorporating new ones, particularly that of 'meeting', these new images maintain Heracles's main physical attributes while leaving in the background any reference to his exploits, which have already served their purpose on his path toward his destiny. ${ }^{49}$

The main difficulty in the interpretation of these vase paintings concerns the hero's condition: he has moved on to immortality and enjoys the company of the Olympian gods. Verbanck-Piérard, rejecting earlier interpretations, argues that the images of Heracles's apotheosis would not imply a double nature mortal and immortal- but rather an intrinsic ambiguity, for the "idea of tension or limit to be surpassed or respected" distinguished his cult in Attica. ${ }^{50}$ Thus the transition to immortality and to commensality with the gods occurs without ruptures or exceptional changes; it is rather a natural development from the hero's close links with his father, Zeus. ${ }^{51}$ Athena's presence beside the hero in these paintings -a characteristic of the vases that distinguishes them from the previous images of him- highlights his membership in the Olympian family and confirms the autonomy of his iconography from the literary tradition. ${ }^{52}$ The close relationship between the hero and Athena is also a feature of the Odyssey and also appears in vase paintings of the Archaic and Classical periods.

It is not always easy to distinguish vases representing Heracles's apotheosis from those in which he is simply depicted as being in the company of one or more gods. In some paintings, it is quite clear that the setting is Olympus, for instance when Heracles is welcomed by Zeus, appears on a car making a celestial journey, strikes a contemplative pose amid the ranks of the gods, participates in the Gigantomachy, is nursed by Hera, or is paired with his immortal wife Hebe, one of the cupbearers of the gods. ${ }^{53}$ Other depictions are suggestive but unclear regarding his divinity, such as those in which he is accompanied by Hermes or Dionysos. ${ }^{54}$

\section{Final Remarks}

This selective survey of images of Heracles from the Classical period demonstrates the continuity between representations of his weariness and apotheosis and a more general evolution in the Greek conception of the hero, in particular the inherent tension between mortality and immortality. The motif of Heracles's apotheosis provided an excellent opportunity to reconsider the artistic representation of extreme exhaustion: while keeping the focus on human mortality, these images suggest an absence of goals that can only be overcome in the exclusive case of Zeus's son. Because Heracles is depicted in repose, his heroic prowess remains implicit, so that his apparent moment of weakness alludes in fact to his superiority. In this respect, that which is actually depicted is distinct from the central meaning of the depiction. The profound and complex cultural change in $5^{\text {th }}$ century Greece, then, brought to the fore a new conception of iconographic expression in which temporality was no longer communicated by the duration of the action represented but 
rather in terms of a series of events leading up to and following the action, many of which are divine, which is to say, invisible to humans and therefore incapable of representation. ${ }^{55}$

\section{REFERENCES}

Bérard, C. (1983) "L'héroïsation et la formation de la cité", in Architecture et société de l'archaïsme grec à la fin de la République romaine: Actes du colloque international organisépar le C.N.R.S. et l'Ecole Française de Rome (Rome, 2-4 décembre 1980), Paris-Rome: 43-59.

Bérard, C. (1984) "L'ordre des femmes", in F. Lissarrague et alii (ed.) La cité des images: religion et société en Grèce ancienne, Paris: 84-103.

Bérard, C. \& Durand, J.-L. (1984) "Entrer en imagerie", in F. Lissarrague et alii (ed.) La cité des images: religion et société en Grèce ancienne, Paris: 18-33.

Boardman, J. (1975) “Herakles, Peisistratos and Eleusis”, JHS 95: 1-12.

Boardman, J. (1985) Greek Sculpture: the Classical Period, London.

Boardman, J. (1981-1999) s. v. "Heracles", in Lexicon Iconographicum Mythologid Classica 5, 1, Zürich.

Bonnet, C. \& Jourdain-Annequin, C. (org.) (1992) Héraclès d'une rive à l'autre de la Méditerranée: bilan et perspectives. Actes de la Table Ronde de Rome, Bruxelles-Rome.

Bonnette, A. L. (1994) Xenophon: Memorabilia. Translated and annotated by A. L. Bonnette; with an introduction by C. Buell, Ithaca-London.

Bowra, C. M. (1966) Landmarks in Greek Literature, London.

Brelich, A. (1958) Gli eroi greci, Rome.

Burkert, W. (1979) "Herakles and the Master of Animals", in Structure and History in Greek Mythology and Ritual, Berkeley: 78-98.

Burkert, W. (1992) "Eracle e gli altri eroi culturali del Vecino Oriente", in C. Bonnet \& C. Jourdain-Annequin (org.) Héraclès d'une rive à l'autre de la Méditerranée: bilan et perspectives. Actes de la Table Ronde de Rome, BruxellesRome: 111-127.

Burkert, W. $\left(2011^{2}\right)$ Griechische Religion der archaischen und klassischen Epoche, Stuttgart-Berlin-Köln-Mainz.

Cook, A. (1906) “Who was the wife of Zeus?", CR 20: 365-378.

Couelle, C. (1989) “Le repos du héros: images attiques de la fin du V̀̀̀ s. av. J.-C.”, in A.-F. Laurens (ed.) Entre hommes et dieux: le convive, le héros, le prophète, Paris: 127-144.

Davies, M. (1995) "Agamemnon's apology and the unity of the Iliad", CQ 45: 1-8.

Davies, M. (2003) “The Judgements of Paris and Solomon”, CQ 53.1: 32-43.

Davies, M. (2004) "The Temptress throughout the Ages: Further Versions of Heracles at the Crossroads", CQ 54: 606-610.

Denoyelle, M. (1997) Le cratre des Niobides, Paris.

Descat, R. (1986) L'acte et l'effort: une idéologie du travail en Grèce ancienne (VIII-V siècle av. J.Besançon-Lille.

Detienne, M. (1960) “Héraclès, héros pythagoricien”, Revue de l'Histoire des Religions 158: 19-53.

Dourado-Lopes, A. O. O. (2003/4) “Héracles na Ilíada”, Kléos. Revista de Filosofia Antiga 7/8: 11-54.

Dover, K. J. (1974) Greek Popular Morality in the Time of Plato and Aristotle, Oxford.

Fagles, R. (1996) Homer: The Odyssey. Translated by R. Fagles; introduction and notes by B. W. Knox, New York.

Farnell, L. R. (1921) Greek Hero Cults and Ideas of Immortality, Oxford.

Finkelberg, M. (1995) “Odysseus and the genus 'hero", G\&R 42: 1-14.

Finkelberg, M. (2000) "The Cypria, the Iliad and the problem of multiformity in oral and written tradition", CPh 95: 1-11. 
Furtwängler, A. (1886-1890) s.v. 'Herakles', in W. H. Röscher (ed.) Ausfübrliches Lexikon der griechischen und römischen Mythologie, Band I, Leipzig.

Gentili, B. (1977) "Eracle 'omicida giustissimo", in B. Gentili \& G. Paione (org.) Il mito greco. Atti del Convegno Internazionale (Urbino 7-12 maggio 1973), Roma: 298-305.

Giombini, S. (2017) "Prodico al bivio. Ancora sull'antilogia", Peitho / Examina Antiqua 1 (8): 187-200.

Guthrie, W. K. C. (1969) History of Greek Philosophy. Volume III: The Fifth Century Enlightenment, Cambridge.

Herzog-Hauser, G. (1952) “Ponos”, in A. F. von Pauly, G. Wissowa, W. Kroll, K. Witte, K. Mittelhaus \& K. Ziegler, Realencyclopädie der klassischen Altertumswissenschaft, Suttgart-München.

Heubeck, A. \& Hoekstra, A. (1990) A Commentary on Homer's Odyssey, vol. 2: Books IX-XVI, Oxford.

Huxley, G. L. (1969) Greek Epic Poetry: from Eumelus to Panyassis, London.

Jourdain-Annequin, C. (1989) Héraclès auxportes du soir: mythe et histoire, Centre de Recherches d'Histoire Ancienne, 89. Annales Littéraires de l’Université de Besançon, 402, Paris.

Jourdain-Annequin, C. (1995) “De l'exploit héroïque à la biographie”, in M. M. Mactoux \& E. Geny (eds.) Discours religieux dans l'Antiquité. Actes du Colloque de Besançon, Paris: 93-114.

Kerényi, K. (1961) "Hercules fatigatus", in H. Rinn \& M. Rychner (eds.) Dauer im Wandel: Festrschrift zum 70. Geburtstag von Carl J. Burckhardt, München: 214-220.

Kirk, G. S. (1962) The Songs of Homer, Cambridge.

Kirk, G. S. (1974) “The mythical life of Heracles", in G. S. Kirk, The Nature of Greek Myths, London: 176-212.

Kirk, G. S. (1977) "Methodological reflections on the myths of Heracles", in B. Gentili \& G. Paione (org.) Il mito greco. Atti del Convegno Internazionale (Urbino 7-12 maggio 1973), Roma: 285-297.

Kullmann, W. (1956) Das Wirken der Götter. Untersuchungen zur Frage der Entstehung des homerischen 'Götterapparatts', Berlin.

Lattimore, R. (2007) The Odyssey of Homer. Translated with an introduction by R. Lattimore, New York.

Levy, G. R. (1934) “The oriental origin of Herakles", JHS 54: 40-53.

Loraux, N. (1981) "Héraclès. Le héros, son bras, son destin", in Y. Bonnefoy (ed.) Dictionnaire des mythologies, t. I, Paris: $492-498$.

Loraux, N. (1989) Les expériences de Tirésias. Le féminin et l'homme grec, Paris.

Mandelbaum, A. (1991) The Odyssey of Homer. A verse translation by A. Mandelbaum, New York.

McHugh, H. (2001) Euripides: Cyclops. Translated by H. McHugh. Edited with introduction and notes by D. Konstan, Oxford.

Merrill, R. (2002) Homer: The Odyssey. Translated by R. Merrill. Introduction by T. R. Walsh \& R. Merrill, Michigan.

Most, G. W. (2007) Hesiod: The Shield. Catalogue of Women. Other Fragments, London-Cambridge (MA).

Mühl, M. (1958) "Des Herakles Himmelfahrt”, RhM 51: 106-134.

Nagy, G. (2005) “Epic hero", in J. M. Foley (ed.) A Companion to Ancient Epic, Malden (MA)-Oxford: 71-90.

Pfister, F. "Herakles und Christus", ARW 34: 42-60.

Philips, F. C. (1978) “Heracles”, $C W 71: 431-440$.

Schauenburg, K. (1963) "Herakles unter Göttern”, Gymnasium 70: 113-133 (with illustrations I-XII).

Schein, S. L. (1984) The Mortal Hero. An Introduction to Homer's Iliad, Berkeley-Los Angeles-London.

Shewring, W. (1980) Homer: The Odyssey. Translated by W. Shewring with an introduction by G. S. Kirk, OxfordNew York.

Schnapp, A. (1987) “Héraclès, Thésée et les chasseurs: les ambigüités du héros”, in C. Bérard, C. Bron \& A. Pomari (org.) Images et sociétés en Grèce ancienne: l'iconographie comme méthode d'analyse. Actes du colloque international (Lausanne 8-11 février 1984). Cahiers d'archéologie romande 36, Lausanne: 121-130.

Seaford, R. A. S. (1984) Euripides: Cyclops. Edited with introduction and commentary by R. A. S. Seaford, Oxford. Shapiro, H. A. (1983) "Heros theos: the death and apotheosis of Herakles", CW 77: 7-18. 
Treu, M. (19682) Von Homer zur Lyrik: Wandlungen des griechischen Weltbildes im Spiegel der Sprache, München. van Thiel, H. (1991) Homeri Odyssea. Recognovit H. van Thiel, Hildesheim-Zürich-New York.

Verbanck-Piérard, A. (1987) "Images et croyances en Grèce ancienne: représentations de l'apothéose d'Héraklès au VI ${ }^{\grave{e}}$ siècle", in C. Bérard, C. Bron \& A. Pomari (org.) Images et sociétés en Grèce ancienne: l'iconographie comme méthode d'analyse. Actes du colloque international (Lausanne 8-11 février 1984), Lausanne: 187-199.

Verbanck-Piérard, A. (1989) “Le double culte d'Héraklès: légende ou réalité?”, in A. F. Laurens (ed.) Entre hommes et dieux. Le convive, le héros, le prophète, Paris: 43-65.

Vernant, J. P. (2007) “Inde, Mésopotamie, Grèce: trois idéologies de la mort", in J. P. Vernant CEuvres. Religions, rationnalité, politique, t. II, Paris: 1376-1385.

West, M. L. (1997) The East Face of Helicon: West Asiatic Elements in Greek Poetry and Myth, Oxford.

West, M. L. (2003) Greek Epic Fragments from the Seventh to the Fifth Centuries, Cambridge (MA)-London.

West, M. L. (2017) Homerus: Odyssea. Recensuit et testimonia congessit M. L. West, Berlin.

Zipper, C. (2000) Lepersonnage d'Héraclès chez Sophocle et chez Euripide et dans l'iconographie correspondante. Mémoire de maîtrise en Lettres Classiques soutenu à l'Université de Strasbourg sous la direction de J. Jouanna et G. Siebert, Strasbourg.

\section{Appendix}

\section{Index of images}

Image 1 (see note 37 above): Coin (stater) from Abdera. Collection of the Martin von Wagner Museum of the Universität Würzburg (inventory Ka $1258=\mathrm{H}$ 6625).

Description: obverse: "AB $\Delta \mathrm{H}$ " - painting of Griffin squatting to the left, to the left in the Zikad field; reverse: "ЕПI $\Phi \mathrm{I} \Lambda \mathrm{A}-\Delta \mathrm{O} \Sigma$ " - painting of bearded Heracles sitting pending to the left over the stone, on which the lion's skin is spread, looks backward over his left shoulder, with his mace in his right hand placed on his right knee, the lefthand reposes on his knee; everything in quadratum incusum.

Former owner: Wellhöfer, Herbert.

Description: "Material and technique: silver, imprinted; dimensions: $23 \mathrm{~mm}, 12.79$ size, 5 height created in Philas, Abdera, in 362 BCE”.

Copyright owned by The Würzburg University.

Image 2 (see note 47 above): Lucanian plate of the British Museum, London (museum number: 1844,0113.1). See LIMC, IV, s.v. 'Heracles', number 911; see also Schauenburg (1963: image XI 3).

Description: "Attributed to the painter of the Long Overfalls. Apulian (Puglia, Italy), ca. 380-365 BCE. Pottery: red-figured plate. Design red on black ground. Low foot; no handles. In a medallion: The youthful Heracles seated to left on a rock covered with the lion's skin, looking to right; he has curly hair, club in left hand resting on the ground, and gorytos or bow-case slung at side, ornamented with wave-pattern; in right hand a cup (?)".

Copyright to the image and the legend owned by The Trustees of the British Museum. Image used in accordance to the British Museum's image terms of use licenced under a Creative Commons license. 


\section{Image 1}

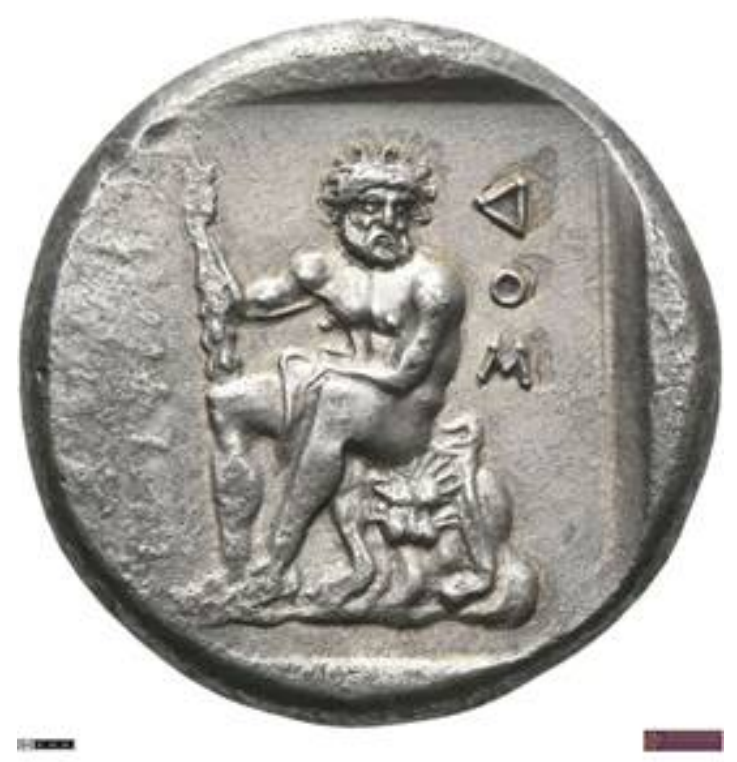

\section{Image 2}

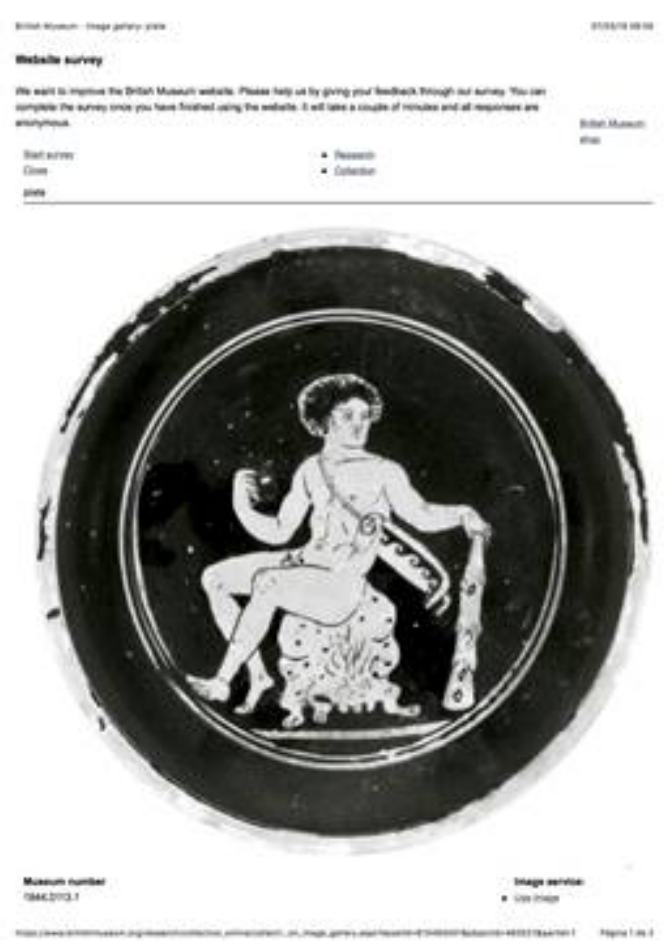




\section{Notes}

* Es Magíster en Filosofía por la Universidad Federal de Río de Janeiro (1996) y Doctor en Filosofía por la Universidad de Estrasburgo (2009). Realizó un posdoctorado en Estudios Clásicos en la Universidad de Brown (2011-2012, 2013 y 2016-2017). Fue Secretario general de la Sociedad Brasileña de Estudios Clásicos (1996). Actualmente se desempeña como Profesor asociado en el Programa de Posgrado en Estudios Literarios (POSLIT) de la Facultad de Letras de la Universidad Federal de Minas Gerais. Integra dos grupos de investigación registrados en el Consejo Nacional de Desarrollo Científico y Tecnológico (CNPq): “Núcleo de Estudos Antigos e Medievais” (UFMG) y “Gêneros poéticos na Grécia Antiga: tradição e contexto” (USP). Se ha dedicado a la literatura griega arcaica y clásica, interesándose especialmente por Homero, Hesíodo y Platón. Sobre estos temas organizó volúmenes colectivos y publicó diversos artículos en revistas científicas.

1 Heracles's persecution by Hera is one of the oldest and most conspicuous aspects of his myth. For Farnell (1921: 100) "'the glory of Hera' is just such an auspiscious name that hopeful and grateful parents might give to a new-born real infant whom they had received from the marriage-goddess". Farnell also observes that the cult of Hera did not exclude Heracles as it did Dionysos, concluding that "the legend of Hera's hostility is not an original fact, but may merely reflect the mythic enmity between Argos, her city whence he was driven, and Thebes, where he became indigenous" (op. cit.: 100-101). Philips (1978) suggests that Heracles's name, which originally meant 'Hera's glory', would first be a title assigned to Hera's husband as well as to her priest. In a later stage of development, this religious title would become the proper name of a hero 'Heracles', whose attributes would be progressively defined by new cultural demands. The evolution from title to proper name would thus explain the diffent usages of 'Heracles' and, consequently, the hero's ambiguous nature. It is nonetheless curious that, afterwards, the hero bearing this name is opposed precisely to Hera by his birth as a consequence of Zeus's infidelity with a mortal. Kullmann (1956: 32-37) surveys Iliadic references to Heracles. For a critical approach to the Homeric Heracles and a review of the bibliography, see also Baurain, "Héraclès dans l'épopée homérique”, in Bonnet \& Jourdain-Annequin (1992: 67-109) and Dourado-Lopes (2003/2004: 11-23).

2 See Il. 9.410-416, Il. 19.78-126 and Od. 5.118-144, especially 134-136. Davies (1995: 5-6) observes that the fact that the dispute between Zeus and Hera is not resolved in the Iliad contrasts with the reconciliation between Agamemnon and Achilles in book 19; this dispute generates two catastrophes, the war of Troy-which is the poem's broader context-and Heracles's life of toil -which is a secondary but important part of the poem, as it provides the main comparandum for the Homeric heroes. In the Odyssey, Odysseus's refusal of Calypso's offer of immortality may be influenced by Gilgamesh's rejection of Ishtar's offer in the Sumerian-Acadian epic poem (see, e.g., Nagy, 2005: 85-86). For the importance of this motif in the characterization of the Homeric protagonists, see Schein (1984: 37-88). The term aethlos refers to Odysseus's challenges in $O d .1 .18$ and 4.170 and those of Heracles in $I l .18 .133, O d .11 .622$ and 624 and Hesiod, Theog. 951, for which see Dourado-Lopes (2003/2004) and my forthcoming study on the meeting of Heracles and Odysseus in the underworld in the Odyssey in a collection of essays entitled Reinterpretando Homero, edited by Teodoro Rennó Assunção and myself.

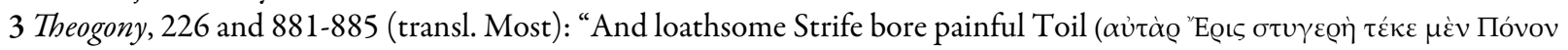

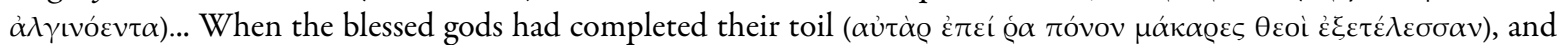
by force had reached a settlement with the Titans regarding honors, then by the prophecies of Earth they urged farseeing Zeus to become king and to rule over the immortals (...)". For a general overview of the god Пiovos in the Archaic and the Classical period see Herzog-Hauser (1952).

4 The moral shortcoming of aergia is alleged by Achilles in $I l .9 .320$ and is the main topic of Works and Days 302-312. See also Od. 19.27 and 24.251 and Works and Days 44 and 498.

5 In his comprehensive survey on the subject of 'work' in Greece, Descat (1986: 1-120) makes clear its social and religious importance and criticizes a common view among scholars that ancient Greeks despised labor in general, and particularly manual labor, as being in itself an inferior form of occupation. For the valorization of work by archaic elegists, see Bowra (1966: 54-79).

6 Farnell (1921: 10) ponders: "Certainly in Homer there is no explicit consciousness of any mystic communion between the human and the divine after death; but he presents us with certain embryonic material of belief out of which such an idea could germinate; just as he presents us with an embryonic theory of posthumous judgement". Citing $I l$. 3.279 and Il. 19.260, Farnell (1921: 10-12) also observes that Patroclus's funeral rites (Il. 23.108 ff.) and Odysseus's ritual offer of honey, wine, and water to the dead (Od. 10.515-530) likely reflect elements of existing cults. Schein (1984: 47-50) supports this hypothesis and proposes a reason for the absence of direct reference to hero cult in Homer (op. cit. 49): "If Homer had introduced hero cults into the Iliad, he would have violated the poem's general Panhellenic orientation as well as its thematic emphasis on mortality and human sufferings and achievements".

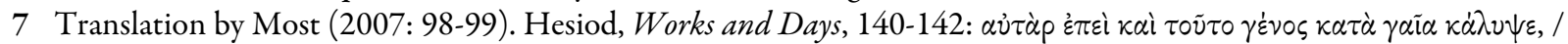

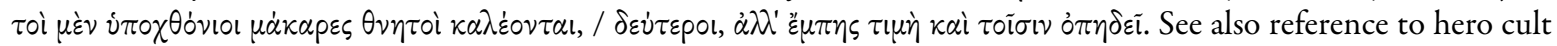


at Works and Days, 654ff (the funeral games for Amphidamos), where $202 \alpha$ (654) extends the notion of labors and suffering to athletic contexts. See Farnell (1921: 14): "Hesiod was aware of many chthonian cults of personages imagined as having once lived on earth, which seemed to him and probably often were a heritage from the pre-Olympian religious period; wherefore he might regard such personages as an older generation of men who were the enemies of the Gods - that is to say, of the Olympians; such, for instance, might appear the Kuklopes, whose altar and worship at Corinth is recorded by Pausanias. In any case, Hesiod gives us, though in puzzling phrase, the evidence that we are seeking- namely, that in his own age there were several chthonian cults of legendary beings imagined by him and his contemporaries as once living men".

8 Farnell (1921: 15) also cites in this context Homeric references to the Dioskouroi, Semele, the myth and cult of Iphigenia, and the children of Medeia, arguing that the latter two myths point to the existence of human sacrifice in Homeric times. To the extent that those who were offered to a god in sacrifice were usually honored in cult, these myths constitute more evidence for hero cult (Farnell, 1921: 18).

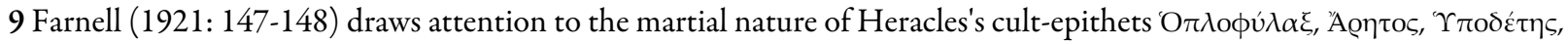

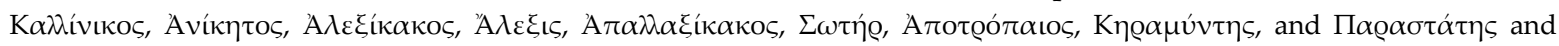
observes "His warlike character seems indicated in a sacrificial inscription from Ionia (...) ordaining a sacrifice to Heracles in conjunction with 'arete' or Valour, and Aphrodite strateia, the Asiatic goddess of armies. (...) As his cult lay such stress on his martial character we may conclude that it was stimulative of the moral virtue of courage, which the Greek ethical philosophers rank so high among the political virtues!”. On the virtuous aspect of Heracles's violence, see Gentili (1977).

10 Burkert (2011: 316-317) and Parker (2011: 243-244); according to the latter, "In a papyrus fragment probably from Aristophanes's Heroes, the Heroes duly speak as a body; they declare themselves guardians of human morality who punish transgressions. (...) Moderns have often tended of late to answer that question in broadly political terms: hero cults are used to legitimate territorial claims or claims to hegemony or the power of a ruling elite or the prestige of individual groups, or simply as a way of forging group identity. Ancients would have given a very different kind of answer: for them what mattered was not the hero as an idea but the hero as a power genuinely effective for good or ill”. The fragment alluded to is Fr. $322 \mathrm{~K} / \mathrm{A}$ Aeneas Tacticus: 31.15 (op. cit., n. 30).

11 Thus West (2003: 204-21, in particular 207, note 21) comments, "I take fragments 20-22 to be from Heracles's reply as he tries to restrain his too bibulous host. This temperate Heracles, the counterpart of the moral hero represented by Pindar and Prodicus, would be a modification of the older tradition". For the appropriation of Heracles in later Greek thought, see Detienne (1960), who highlights (22-24) the importance of an 'obedient' Heracles representing of legality and tradition, observes (24): “(...) l'entrée d'H. dans l'hagiographie pythagoricienne n'était qu'une étape de la lente opération qu'avait commencé la lyrique chorale, dès le temps de Stesichore”. Loraux (1981: 496-497) stresses the changes imposed on the hero by rhetoric and philosophy. In a later study, she observes that the substitution of $\tilde{\alpha} \theta \lambda \circ \varsigma$ by $\pi \dot{0} v 0 \varsigma$ to express Heracles's exploits in $5^{\text {th }}$ century BCE is "une fructueuse opération idéologique (...) Lorsque le pónos est source de mérite, à l'issue d'une longue histoire qui, dans la société, a permis la complète distinction du travail servile et du métier de citoyen, lorsque l'homme libre est clairement défini comme celui qui ne dépend pas d'autrui pour sa subsistance, alors pónos remplace âthlos et, ne pouvant plus obéir, Héraclès devient libre" (Loraux, 1989: 54-71, particularly 70-71).

12 According to Mühl (1958: 108), Heracles's apotheosis shows the influence of mythological narratives in which man "lebt also im vorhandenen Körper fort, nur an anderem Orte, in der unmittelbaren Nähe der Gottheit". He cites as examples Agni, the personification of sacrificial fire in Hindu religion, and notes the special importance of the Eraniel region in India, from which this kind of conception spread to influence Mithraism, Mandaism, Judaism, Christianity, and pre-Christian Greek beliefs. Quoting Cicero (Tusculanes 1.32), he observes that Heracles was transformed into a hero of social conviction and social acts. Schauenburg (1963: 117 and note 5), on the other hand, rejects Mühl's interpretation, arguing instead that Heracles's travel in the quadriga was one of the few possibilities that an artist had for representing the hero's acceptance into the Olympian community and therefore is not necessarily related to Near Eastern conceptions or Greek mystery cults.

13 See again Farnell (1921: 149-154, in particular 153-154): “The Athenian-Eleusinian legend only expresses the eagerness to settle him as full citizen in their land; he becomes initiated as every native of Attica would desire to be. But in spite of all this, the hero never became one of the genuine chthonian powers, and his occasional association with these is rare and incidental. The lower realm had no hold on him; his relations with the ghost-world are hostile”.

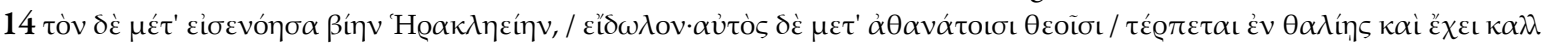

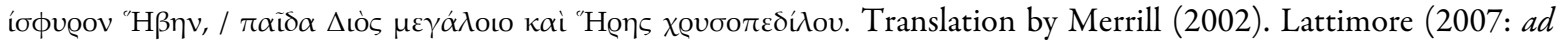
loc.) and Shewring (1980: ad loc.) exclude lines 602-604 from their translations, while Werner (2014: ad loc.) retains them; von der Mühl (2010: ad loc.) and West (2017: ad loc.) retain 602-603 but exclude 604 from their editions, both referring to the fact that the same line appears in Hesiod (Theogony 952) and was already excluded in antiquity; van Th iel (1991: ad loc.) retains all three lines. 
15 In the meeting between Odysseus and Heracles at $O d$. 11.601-627, line 602 is particularly distinctive: thus the term eidōlon appears in suspisciously artificial and unnecessary enjambent, again suggestive of interpolation, and the explanation appears superfluous. Translators of this passage usually augment the original text in order to smooth out the enjambment; thus Merrill (2002: ad loc.) inserts the adverb 'only'; Mandelbaum (1990: ad loc.) places lines 602-604 in parentheses and inserts "that is to say"; and Fagles (1996: ad loc.) inserts 'I mean' to begin line 602 (line 692 in his translation -"His ghost I mean (...)”). Indeed, it might be asked how, if Odysseus meets only an eidōlon of Heracles, the two would be able to converse. See Mühl (1958: 119): “(...) mit beginnendem 6. Jahrhundert in den Mythos um Herakles die Himmelfahrt rezipiert worden ist. Das war ja auch die Zeit, wo der Orphismus aufzublühen begann, der in seinem Erlösungsbedürfnis dahin strebte, die Menschen gottähnlich zu machen”. He also refers to the description of the Elysean Plains (Od.4.564-568) as an example of a possible Orphic interpolation (op. cit.: 119-133). In the Theogony, the interpolations would have been made at the time of Peisistratos by Orphic authors and by Onomacritus; the influence of Orphism would extend this final conception of the hero's or the divine individual's existence to writers as important and diverse as Parmenides, Sophocles, Pindar, Plato, Lucian, Ovid, and Seneca. Other similarities may also be found in Atharva Veda 4, 16.1-5; Plutarch, De superstitione 166d; Psalm 139.7-10 in the Septuagint; Pseudo-Apollodorus, Library 2.160; the II Kings 11 (Elijah), and Acts of the Apostles 1.9. The ascension of Jesus would be the final point of this series of influences, as already observed by Pfister (1937). Kirk (1974: 179) considers Heracles's divinization as told in Od. 11.601-608 an interpolation added to the poem just after the conclusion of its final monumentalization around 700 BCE. On the rich scholarly discussion concerning this subject, see Heubeck and Hoekstra (1990: ad loc.), who contrast the rigorous observance throughout the Odyssey of the condition of physical death with the presence of an eidolon in the underworld.

16 On the influence of Orphic thought, note in Parmenides the use of the adjective $\pi \circ \lambda$ vi by Mühl (1958: 115-116) to the expression $\Delta i \kappa \eta \pi 0 \lambda \dot{\tau} \pi \circ$ เvos in Orphic fr. 158 Kern. Parmenides's poem also has some affinities with Orphic frs. 78 and 316 Kern. A new moral perspective on effort appears when, instead of the substantive Tóvos, writers begin using this adjective, which, Mühl argues, alludes to the existence of two different worlds, since

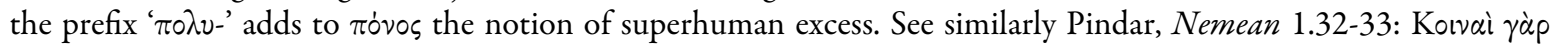

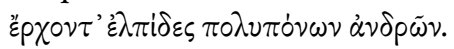

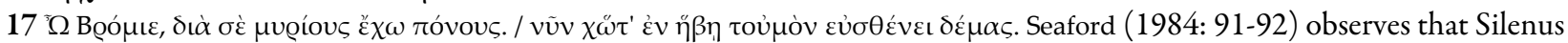
is addressing a statue of Dionysos in the scene and that the expression $\delta \dot{\alpha} \sigma \dot{\varepsilon}$, often found in prayers, is here a kind of blaming, in accordance with the topos of lamenting toil as an inevitable aspect of human life.

18 Od. 4.564-568. See Kullmann (1956: 31-34), for whom it is possible that the Iliad "consciously ignores" Heracles's apotheosis; he adds (131) that Heracles is not represented as immortal in the Iliad because only occasionally do Homeric heroes receive divine help. Kirk (1974: 178-180) tentatively dates the hero's apotheosis to the 7th century BCE, the most likely period for some of the interpolations into the Odyssey and the Hesiodic poems, just as Heracles's death on Mount Oeta was added to an older myth that a poisoned veil sent by Deianeira was responsible for his demise. See also Loraux (1981: 494): "C'est l'humanité qu'en lui-même Héraclès affirme et dépasse tout à la fois lorsqu'il s'affronte à des monstres. (...) Mais seul l'anéantissement de l'Héraclès humain permet l'apothéose du fils de Zeus, et l'on ne s'est peutêtre pas assez avisé de la tension qui constamment renvoie Héraclès de la mort des mortels à la mort qui immortalise". Farnell (1921: 170-174) emphatically asserts that the self-immolation on Oeta could only have come from an 'oldestablished ritual'. Shapiro $(1983: 10,15-18)$ argues that death by self-immolation may have been conceived to fit his immortality; thus Heracles's apotheosis would be but one more facet of his incredibly diverse mythology, some of it certainly very old, dealing with victory over death and immortality. In addition to fighting Hades himself (Il. 5.395-397), Heracles also faces death in the last three labors of his so-called dodekathlos, those involving Geryon's cattle, the apples of the Hesperides, and the capture of Cerberus, the latter two of which are mentioned in the Iliad (op. cit.: 10). Heracles's self-immolation would solve the problem of the hero's passage to immortality: using fire as a purifying element, it would link him to old funerary practices. Associating various aspects of Heracles's legend, the events leading up to his death may have been assembled for the first time by Sophocles or Bacchylides, who would have promoted new cultural practices (op. cit.: 16-18). As discussed presently, the representation of the apotheosis itself was created by the ceramists. On the exceptional afterlife of some Homeric heroes, West (1997: 166-167) observes that the Elysian Plains that will be home to Menelaus (Od.4.561-569) correspond to Hesiod's Isles of the Blessed, where the race of heroes resides after their era has passed (Works and Days 167-171).

19 See Zipper (2000: 260-261): “Le répertoire iconographique du cycle d'Héraclès connaît donc des changements dans le choix des thèmes, plaçant les images à sujet ancient à l'état de simples survivances de l'imagerie précédente, pour presqu'exclusivement montrer Héraclès dans le cycle des Hespérides ou bien dans celui de son apothéose (comprennant bien-sûr l'apothéose elle-même -même, mais également, l'accueil parmi les dieux et le repos du héros...). Par ailleurs, les représentations de ces thèmes, et en particulier de celui du Jardin des Hespérides, semblent exclure toute idée de lutte et d'épreuve à subir. L'idée du repos et du bonheur se développe, passant de leur conquête, aux VI ${ }^{\text {ème }}$ et Vème siècles (où 
ces thèmes sont peu représentés), à une acquisition momentanée au $\mathrm{V}^{\mathrm{ème}}$ siècle, puis à leur conquête définitive au IV ${ }^{\mathrm{ème}}$ siècle. Ce n'est donc plus les obstacles de sa vie qui intéressent, mais la poursuite d'un idéal concevable par l'humain et accessibe pour lui. (...) Héraclès a perdu sur le boûcher ce que son personnage avait de 'terrestre' (c'est-à-dire son corps) pour devenir une pure incarnation du repos de l'âme qui jouit maintenant d'une sorte d'ataraxie". See also Loraux (1981: 494 and 497): “(...) dans l'Athènes du IV ème siècle les travaux gémissants s'effacent au profit de l'harmonieuse félicité, ce choix témoigne du climat de la cité, sans remettre en question le sens de l'immortalité d'Héraclès. (...) Les représentations figurées suivent le mouvement et, sur les vases comme sur les métopes des temples, le héros combattant cède le pas au héros réconcilié, la sueur et le sang s'effacent devant la béatitude des Bienheureux". Verbanck-Piérard (1989: 54) links this tendency in Heracles's representation to his cult: "les images et les récits de l'Apothéose conçue comme un passage se sont développés avec une acuité particulière parallèlement à la valorisation intentionnelle du culte divin à Athènes dès le $\mathrm{VI}^{\mathrm{ème}}$ siècle”; see also note 99. This general shift can also be observed in Niobides's famous calix crater in the Louvre (G 341), as observed by Denoyelle (1997: 36-37): on face 'A' of the vase, Heracles appears laureate and with an ostensibly tired expression in a typical representation of the divinized hero after his apotheosis. The entire scene reproduces a mural by Polygnotos and Macon, a 'mélange entre description naturaliste et symbolique religieuse', that was much appreciated in Greek painting, as confirmed by another oinokhoe from the Louvre (L 62), assigned to the same painter and "décorée d'une rencontre entre un Héraclès juvénile et Athéna de part et d'autre de l'olivier sacré".

20 See, for instance, Guthrie (1969: 48), who compares the Athenian intellectual revolution of the $5^{\text {th }}$ century BCE with that of $18^{\text {th }}$ century Europe, which looked to classical Athenian authors as models. According to Bérard (1983: 52), Athenian aristocrats evoked important aspects of the royal tradition but "prennent grand soin de leur ôter tout aspect à tendance totalitaire par le biais de l'héroïsation; celle-ci les décontamine”. Despite the resistance of the tyrants, who sought to undermine the heroic function through an "exploitation idéologique du monument", the nobles used heroization as "une façon détournée de récupérer le pouvoir des rois, légendaires ou non, des chefs de guerre, des fondateurs de villes illustres, pouvoir qui ne pouvait plus s'exercer de façon directe dans le cadre de la cité historique” ( $o p$. cit.: 59). The symbolic appropriation of Theseus by Cleisthenes is, in this historical context, comparable with that of Heracles by Peisistratos: “... de même que Pisistrate s'était fait représenter en Héraclès, ramené sur l'Acropole / l'Olympe par la belle Phyé déguisé en Athéna (manipulation de type religieux, calquée sur un hieros gamos), Clisthène n'a pas dû récuser quelque assimilation avec le héros athénien qu'il prônait, pratique familière dans toute l'Antiquité" (op. cit.: 48). See also Boardman (1975: 1-12).

21 Xenophon, Memorabilia 2.1.21-34; Diogenes Laertius 6.71.

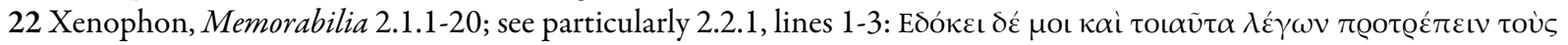

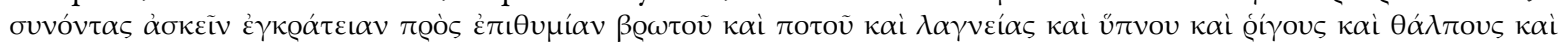

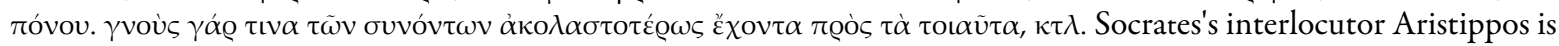
introduced by Xenophon as "one of his [scil. Socrates's] companions who was too indisciplined in this context". For

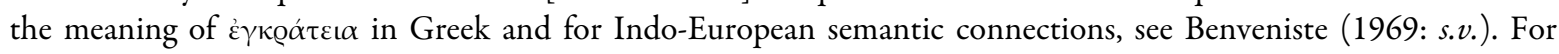

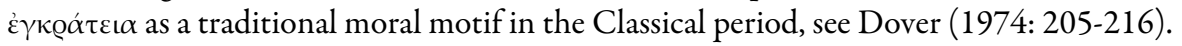

23 Xenophon, Memorabilia 2.1.22. Note particularly how the Platonic-Socratic verb à $\pi \circ \dot{\varepsilon}^{\varepsilon} \omega$ is used in the narrator's characterization of the point Heracles's life at which the story is set (2.1.21): "going out to a quiet spot, he sat down

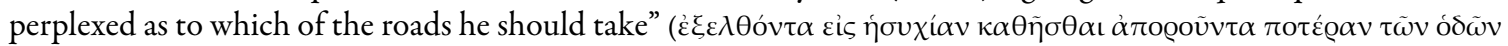

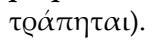

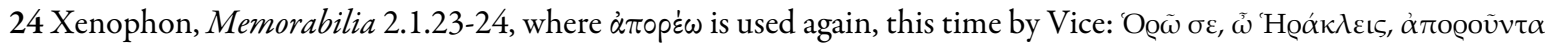

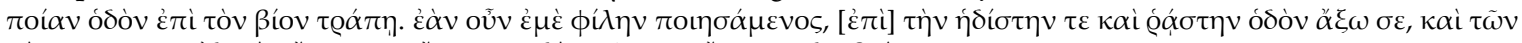

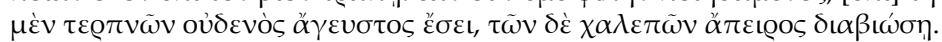

25 Xenophon, Memorabilia 2.1.27-28. Translation by Bonnette (1994: 39-40). See particularly 2.1.28, lines 1-5: $\omega \tilde{\omega} v \gamma \dot{\alpha} \varrho$

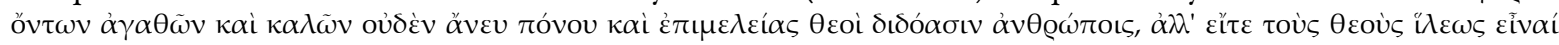

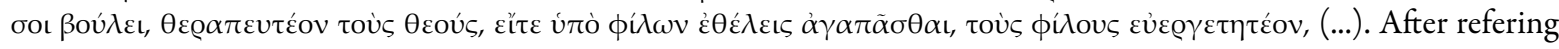
to Xenophon's version of Scopas's apology of virtue, Loraux (1989: 70) remarks that “désormais l'on n'échappe plus à ce grand processus de récupération d'Héraklès, conçu comme le symbole du pónos”; see also 142-170; particularly 145. On the shifts of the Greek hero conceptions in general see Pfister (1937: 42): "Das Ideal der heroischen Tat wird in der späteren Zeit zu einem Ideal des leidvollen Mühen, wie sich ja ganz allgemein das althellenische Heroenideal mehr und mehr dem Ideal näherte, das in den christlichen Heiligen sich verköperte”. For a Christian reference to Heracles as a model of virtue, see Saint Basil, Discurse to the Young 5.61-65.

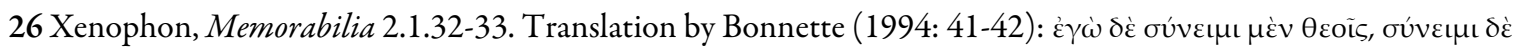

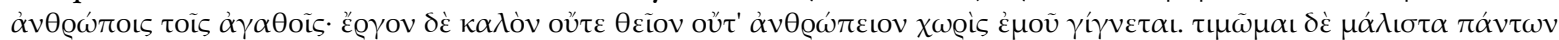

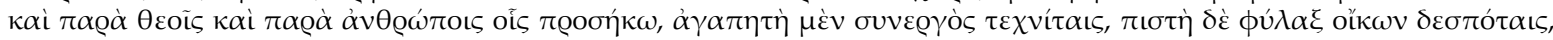

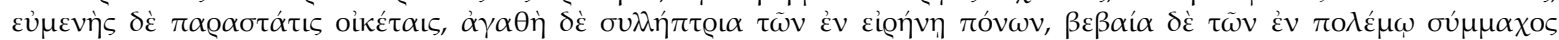

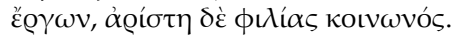


27 Observing the differing representations of Heracles by various classical Athenian authors, Burkert (1992: 114-115) concludes that his civilizing role dates to the $5^{\text {th }}$ century, arguing that he could only be integrated into sophistic thought because he was already established as a civilizing hero. In making this argument, Burkert refers to Kirk and Gentili in Gentili \& Paione (1977: 285-297 and 298-305; particularly 29 and 304).

28 See Finkelberg (1995: 10, note 52): "Characteristically, it was Odysseus who, again together with Heracles, was adopted as an exemplary figure in the vein of Prodicus's exegesis by the fifth-century philosopher Antisthenes and later by both the Cynics and the Stoics. The reasons why these two were chosen as a philosopher's ideal lie in their self-restraint, endurance of hardships, disregard for indignities and humiliation, and in their readiness to serve the common good".

29 Ambiguity in the identification of religious and mythological figures is frequent in Greek vase painting and, to a certain extent, inevitable, both because the images representing gods are contemporary with vases showing mortals in their ordinary activities and, more fundamentally, because divine anthropomorphism often blurred the visual differences between mortals and immortals. See Schnapp (1987: 121-130; in particular 121): "La figuration du héros ne peut pleinement exister dans son imagerie que par son contraire. Pour figurer le héros il faut le confronter aux hommes qui font la cité". See also Bérard \& Durand (1984: 33): "Les dieux grecs sur les vases sont à forme humaine, ils ne peuvent donc pas échapper au geste. Ils sont à leur tour inclus dans l'ensemble des programmes gestuels caractéristiques du monde grec. (...) Il n'y a pas d'autres moyens pour l'image de raconter les être mythiques que de les situer par rapport aux gestes des hommes parmi lesquels ils interviennent".

30 In Burkert's opinion (1992: 124-127), Heracles would be, from the $7^{\text {th }}$ century on, an atypical, abnormal warrior, the non- or anti-hoplitês, basically the one 'who helps' and, consequently, a representative of a more fundamental form of violence. Heracles's labors are already mentioned in $I l .19 .133$, though they are not quantified; they were apparently systematized for the first time around 600 BCE by Peisandros of Rhodes, the author of an epic about Heracles that is not extant. See Burkert $\left(2011^{2}\right.$ : 307 with note 21). Ancient iconography representing Heracles's death and apotheosis are available in Boardman's entries for 'Heracles' in volumes IV and V of the LIMC (1981-1999), items VIII.2847-2938; among many images of the hero in the company of one or more gods, I take as possible allusions to his apotheosis those in which he has Zeus by his side (Boardman,1981-1999: item IX, sub-item 'o', numbers 3371-3385) or in which he appears among many gods (idem, ibidem: item IX, sub-item 'p', numbers 3386-3402).

31 On the difficulty of classifying Heracles's reprentantions after the $5^{\text {th }}$ c. BCE, see Schauenburg (1963: 130-131): "Überblickt man die gesamten unteritalischen Vasenbilder aus dem Herakles-mythos, so ergibt sich, daß die hier untersuchte Gruppe -Herakles im Verein mit verschiedenen Gottheiten- auffallend umfangreich ist. Nur vereinzelt kann die Szene dabei auf eien konkret faßbaren mythologischen Moment festgelegt werden. Dargestellt wird das Ausruhen des Heros von der Mühsal seiner arbeiten, ein tatenloses Zusammensein oder ein ruhiges Gespräch mit Gottheiten, das allenfalls durch die -meist nicht eigentlich durchgeführte- Bekränzung des Herakles mit einer gewißenn Handlung erfüllt wird".

32 Mühl (1958: 113). The relative novelty of Heracles's apotheosis in contrast with other parts of his legend has often been noted. Shapiro (1983: 11) refers to the once influential opinions of Nilsson (1932) and Kirk (1974). An older exception to these positions was that of Wilamowitz-Möllendorff $(1895,1: 19-20)$, who believed that the apotheosis already formed part of the legend before the Archaic period. However, according to Mühl, this point of view is not longer tenable; thus, citing parallels with the New Testament (Mark 16.19 ff; John 20.17; Acts 9.3 ff), he concludes (1958: 133): "In der Vorstellung einer unmittelbaren Vereinigung eines Begnadeten mit Gott, wie sie uns schon der altorientalische Mythos und -von diesem ausgehend- der Mythos vom griechischen Nationalheros Herakles zur Anschauung brachte, bezeugt sich spezifisch orientalisch Denkhaltung".

33 Again according to Mühl (1958: 113), the prophet Elisha's influence is particularly remarkable, being observable not only on the Jews but also on other ancient civilizations (including Greece). It must be kept in mind, however, that other Near Eastern elements are present in Heracles's myths, most conspicuously the narrative of his birth, which has obvious affinities with Egyptian beliefs. On this subject, see also Levy (1934) and Philips (1978), the latter of whom speculates with subtlety and the necessary prudence in this regard; see also Nagy (2005: 71-90, particularly 76).

34 In the workshops of Eritrea and Midias, among others. This general shift in heroic representation was observed by Couelle (1989: 131): "Le héros n'est plus saisi en pleine action, au moment de la performance, mais apparaît comme figé, au repos, en un temps idéalisé en compagnie de plusieurs figures féminines. (...) la désignation du héros ne passe plus par l'acte hérö̈que mais par l'organisation spatiale de personnifications de concepts autour d'un héros passif”.

35 Furtwängler (1886-1890: 2160-2175; 2160 for the quotation): "Einen besonderen Reiz mußte es für die Künstler haben, den immer thätigen, strebenden, unermüdlichen Heros ermüdet, den rastlosen rastend, den vom Schicksal gequälten traurig und sinnend darzustellen. (...) Sie thaten dies schon im 5. Jahrhundert, natürlich noch nicht in Statuen, am wenigsten in solchen des Kultus, wohl aber in kleineren freien künstlerischen Produkten”. See also Schauenburg (1963: 126, note 90) and Kerényi (1961: 215, notes 2 and 3). 
36 Published in the Berliner reproductions of the British Museum's gems, number 533. I quote Furtwängler's definition (1886-1890: 2160, my translation); he adds other Italian scarabs of the Severe Style depicting the same motif: a scarab (its owner unknown; published by the British Museum) similar to the first, with the sole difference of presenting the hero turned to the right of the object (i.e., showing but his left profile, whereas in the first scarab he turns to the left and shows the right); a scarab on which Heracles "den Kopf in die Hand stützt, während er auf einer Amphora (mit der er sonst zum Brunnen geht) sitzt und darunter noch mehr Amphoren angedeutet sind"; a similar scarab, but without the amphoras, displays the hero once more resting his head on his hand; a scarab, this time displaying the hero standing but with a tired look, leaning his right leg on an unidentified object (perhaps a stone), with his right arm on his leg and head resting on his right hand. This scarab represents the same scheme later used on the metope with the Nemean lion on Zeus's temple in Olympia, "deren Künstler es wohl schon vorgefunden hatte und nur in neuer Weise auf die Darstellung des Löwenabenteuers anwandte” (idem, ibidem: 2160).

37 Coin (stater) from Abdera (Boardman, 1981-1999: vol. IV, n. 949, dated between 411/410 and 386/385 BCE; see “Appendix: Index of images. Image 1"). The description is Furtwängler's (1886-1890: 2161); he also refers to other pieces of the second half of the $5^{\text {th }}$ century from Phaistos and to "das Bild einer attischen Vase derselben Zeit, wo der bärtige Heros ausruhend und traurige dasitzt, ohne Trinklust, so daßs der Silen, der zur Bedienung vor ihm steht, ganz betreten und scheu verwundet ist (Berliner Vasen, 2534)". See the reproduction at Lexicon Iconographicum Mythologiae Classicae (1981-1999) -henceforth LIMC-, IV, n. 949.

38 Furtwängler (1886-1890: 2161) comments on the representation of heroes in the $5^{\text {th }}$ century, "Die Characterizierung des Heros durch die Bildung des Kopfes macht in dieser Periode bereits groß Fortschritte, nachdem man sich in der vorigen nur auf gewisse Äußerlichkeiten beschränkt hatte. Selbst die Vasen laßen uns hier etwas von dem ahnen, was die große Kunst bereits versuchte. Da wo der archaische rotfigurige Stil des 6. Jahrhundert sich in den Übergangsstil des Anfangs des 5. Verwandelt, begegnen wir schon dem Versuche, den Kopf der Herakles durch eine besondere Augenbildung zu charakterisieren; statt des gewöhnlichen mandelförmigen giebt man ihm ein besonderes hochgewölbtes der kreisrunden Form sich nährendes Augen, das dem Ausdrucke eine gewisse 'torvitas' giebt. Bei Euphronios kann man das Auftreten dieser Bildung gut beobachten; auf seinen älteren Werken, den Geryoneusschale und dem Antaioskrater findet er sich noch nicht, wohl aber auf der späteren Eurystheusschale (...); auch auf der Euphronios verwandten Amazonenvase (...)". Other representations of Heracles in repose can be found among the works listed in Boardman(1981-1999), vol. IV, sub-items II.2 and II.3, number 271-1007; particularly in vol. IV, 2, subitem II.2, letter 'v', n. 660-737, 'leaning on the club', and sub-item II.3, n. 911-1007, 'sitting'.

39 Graphic reconstitution proposed by Boardman (1985: 46) of the twelve metopes of Zeus's temple at Olympia (also in Boardman: 1981-1999: vol. V, n. 1705; the metope representing the fight with the Nemean lion is on the west side; the other representations of the entire dodekathlos can be found in Boardman's contribution to the LIMC (1981-1999: vol. IV, sub-item IV.a, n. 1697-1761). The quantity of Heracles's labors basically varied in antiquity between ten and twelve. For West (1997: 466), the assignment of the hero's exploits to a group in this way is unparalleled in antiquity; he notes that, although "the motif of a king setting a hero a difficult task or tasks is by no means unique in Greek mythology (...) they are normally limited to a sequence of three, as in the case of Bellerophon" (see also p. 472). As observed earlier, it has been believed since antiquity that the gathering of the dodekathlos was the work of Peisandros of Rhodes (dated by Wilamowitz to the $6^{\text {th }}$ century BCE but by Huxley to the middle of the $\left.7^{\text {th }}\right)$, on which see Huxley (1969: 100), Shapiro (1983: 9), and Burkert (1979: 78, note 2), though this origin for the labors has not been proved. On the notion of a 'biography' made up of 'the labors', see also Jourdain-Annequin (1995). In his commentary on the twelve metopes of Zeus's temple in Olympia, Boardman (1985: 33-50) discusses its artistic quality and psychological subtlety.

40 The killing of the Nemean lion was certainly one of Heracles's most familiar labors in antiquity, as is evident in its popularity in vase paintings (Burkert, 2011:323).

41 As noted by Boardman (1985: 38). This manner of representing the labor is also found in contemporaneous engraved jewelry. The traditional representation of the hero in action struggling with the lion varies according to the possibilities of intertwining the human body with that of the animal (this more traditional approach can be seen, for instance, in the first metope to the east of the Hephaisteion, which was sculpted in the beginning of the second half of $5^{\text {th }}$ century BCE).

42 Kerényi (1961: 214-220). The interpretation of the first reconstruction of this sculptural group, criticized by Kerényi, is that Heracles is leaning over a recently slaughtered lion with his head resting on one hand, reflecting somberly on his former and future weariness (1961: 215, summarizing the text of the German publication about excavations at Olympia, volume III, 1897, 157). A. von Salis in the Winckelmannsprogramm of Berlin (1956) similarly argues that what torments Heracles is 'anticipation' (Vorgesicht), insofar his 'internal eye' sees everything before, the enormous burdens to be borne on his shoulders, and the dragons and other animals that he must slay (Kerényi, op. cit.: 216). Boardman (1985: 38) offers a different interpretation: "The horizontal element in 'I' [scil. the first metope] (Athena and no doubt Hermes' arms, Heracles' thigh, the lion) enhances its mood of quiet, almost depression. (...) And in the 'I' 
the artist catches the mood of the first of such a dire series in the exhaustion of the young, still beardless hero. Hermes attends this inauguration, and, as go-between of hell and earth, the dragging of Cerberus on 'II'".

43 Pointing out the Christian assumptions on which previous interpretations implicitly rest, Kerényi (1961: 217-220) observes that the first metope is not even about a prophet's vision or an ancient soothsayer but rather about what may happen to the hero himself if he is unable to foretell the future (as opposed, for instance, to Amphiaraus). The anticipation of one's own sufferings plays a major role in the sacred history of Christianity, which, of course, differs fundamentally in its outlook from Greek myth: "nicht etwa die Frage nach der Möglichkeit der Vision einers Sehers, eines antiken Wahrsagers, der in die Zukunft blickte und alles voraussah, nur gewöhnlich das nicht, was ihn selbst treffen sollte! Bei einem Wahrsager-Heros wäre solch eine Vision möglich gewesen, kaum bei Herakles, der das nicht war. Das Vorgesicht der eigenen Leiden hat seine wesentliche und charackteristische Bedeutung in der heiligen Geschichte des Christentums. Diese unterscheidet sich auch dadurch in ihrer besonderen Art vom griechischem Mythos, auch vom Heroenmythos. Die Heroenmythologie ist voll leidender Gestalten, die bei lebendigem Leibe und manchmal noch in der Unterwlet geplagt werden. In ihre Reihe gehörte Herakles, ehe er mit verjüngtem Leib auf den Olymp genommen wurde. Die Heroenleiden sind dennoch nur Mythos, höchstens Quasi-Geschichte und nicht Geschichte in jenem konkreten Sinne, wie die heilige Geschichte des Christentums. Der Unterschied ist der gleiche, oder doch von der gleichen Art, wie ihn Aristoteles zwischen Dichtung und Geschichte angibt" (Kerényi, op. cit.: 216-219, 217 for the quotation).

44 See Ps.-Apollodorus, Library 2.5.1 and the observations of Kerényi (1961:219-220). The decisive portion of the scholia for interpretation of the sculptural group reads "experrectus mira damnum celeritate correxit", "awaken, he recovered the loss [scil. of time] with wonderful speed”. The conjecture about Hera being the source of the sleep, entertained by the scholion - "vel odio Junonis, ne ei caelestes honores contingerent, vel fatigatus"- is irrelevant to the discussion here, for, whatever its source, the need for sleep manifests the limits imposed by the hero's mortality. Hypnos also works for Hera in the $\Delta$ iòs $\dot{\alpha} \pi \dot{\alpha} \tau \eta$ (Il. 14.153-362) and the fact that he overpowers Zeus himself speaks for itself (he also mentions that he has done it in the past in 242-261).

45 Kerényi (1961: 220).

46 For Hermes psykhopompos see Burkert (2011: 243-244). There is only a fragment of Hermes's left leg (as can be seen in the reconstruction of the metope), but it is not mentioned by Kerényi (1961), perhaps because he assigns this fragment to another metope (though he says nothing about it in his study). Boardman (1985: 38-50), who includes Hermes in the first metope and does not consider Kerényi's interpretation, offers only a vague explanation for Hermes's presence in the metope ("Hermes attends this inauguration"). He proposes (1985: 38) the god's presence in both cases but limits to metope XII his role as a mediator between the earth and the underworld, though it may in fact be more natural to suppose his function to be the same in both cases. It is therefore important to approach Kerényi's (1961) and Boardman's (1985) studies as complementary, both interpreting similarly Hermes's presence both in the first and eleventh metopes as the mediator god between the living and the dead, since the two exploits occur in the afterlife.

47 Two other good examples of the figurative representation of Heracles's weariness are (a) a Lucanian plate in London that shows the hero sitting and leaning on his club (British Museum, catalog number F 131; see "Appendix: Index of images. Image 2"); referred to by Schauenburg: 1963, illustration XI 3; reproduced and commented on in Boardman (1981-1999: vol. IV, n. 911), who dates it between 375 and 350 BCE, and (b) an Attic red-figure bell-crater from Palermo (n. 13.840), contemporary with Zeus's temple in Olympia, of c. 450 BCE, that shows him sitting next to his assistant Iolaus, who bears his armor, and near Eurystheus, who sits on a throne and addresses him (referred to by Schauenburg, 1963: 126 and note 91, who reproduces it in his illustrations, number IX.1 and IX.2, and by Kerényi, 1961: 215).

48 Verbanck-Piérard (1987: 193) speaks of the impossibility of precision regarding the origin of the cult and proposes six stages in the evolution of the representation of Heracles's apotheosis between 570 and 500 BCE, when these pictorial motifs were the most widely diffused: (1) pseudo-narrative formula of a procession; (2) the quadriga for the departure to the Olympus; (3) in the last third of the $6^{\text {th }}$ century, Heracles's meeting with Athena (mostly in work from the workshop of the painter Anthimenes), his coronation and pouring of libations; (4) in the period from 540-500 BCE, Heracles sitting among the gods; $(5)$ in last third of the $6^{\text {th }}$ century BCE. Heracles as a musician; and (6) Heracles celebrating. The quality and diversity of the images indicate that "pour les principaux peintres attiques de la seconde moitié du VI ${ }^{\grave{e}}$ siècle, l'apothéose d'Héraclès est au centre des préoccupations artistiques et religieuses (...) La diversité des nouvelles images traduit un souci de réflexion, un véritable travail conceptuel. Il paraît certain que la notion d'Apothéose ne correspond pas à une catégorie iconographique déterminée; mais elle éclaire les intentions communes d'un vaste ensemble de motifs. Ceux-ci viennent se greffer, à partir des années 570-560, sur la vision traditionnelle d'Héraklès, héritée des ateliers protoatiques, béotiens et corinthiens. Une dimension supplémentaire, spécifiquement athénienne, investit le personnage: Héraklès, en pleine gloire, figure parmi les divinités protectrices de la Cité” (op. cit.: 193). 
49 Ovid includes a quadriga as part of Heracles's mythography at Metamorphoses 9.266-272, thereby attesting to the possible influence of Greek or Roman vase paintings on his depiction of the hero. See Mühl (1958: 51) and, especially, Verbanck-Piérard (1989: 51), who observes that, at that time in Attica, Herakles's strong presence in cult contrasts with his relatively poor mythography, which is also the case with the relationship between his cult and his mythography in general. Verbanck-Piérard further argues that Heracles can be considered one of Attica's protector gods given the broad diffusion of his cult in the region, the social pluralism of his worshippers (thus, for instance, after $490 \mathrm{BCE}$ he is often associated with the hoplites of the new democracy), and the lack of evidence of his heroization. "À Athènes, mais aussi, n'en doutons pas, dans bien d'autres cités, Héraklès apparaît de plus en plus au centre d'une tradition homogène et cohérente où se rejoignent le thème du 'Bon Mangeur', le motif du dieu au banquet, la convivialité sociale et rituelle qui propose, parallèlement à la $\theta v \sigma i \alpha$ et sans heurts, diverses possibilités d'investigation du divin” (op. cit.: 53).

50 Verbanck-Piérard (1989: 45-47; 51 for the quotation), according to whom the dualist interpretation of Heracles could trace back to Herodotus 2.44, since in the historian's time the double cult of Heracles was hardly an orthodoxy: "Dans le système d'Hérodote, qui inscrit deux Héraclès dans deux temps différents de l'Histoire, et qui révèle la lumineuse ancienneté du dieu, la notion de passage, l'idée même d'apothéose n'ont pas leur place”. Verbanck-Piérard also (note 27) identifies in Herodotus similar explanations for the double nature of some gods and concludes (op. cit.: 51-52): "(...) l'Apothéose ne s'inscrit nullement dans les rites. Le culte ne dit pas la double nature d'Héraklès: il souligne davantage la double nature des fidèles qui se présentent au dieu, en situation cruciale de passage, de changement, ou en quête de protection contre tous les dangers (...). (...) Héraklès peut s'adresser à tous ceux qui ne vivent qu'en marge de la polis: (...) l'un des rôles essentiels de l'Héraclès attique est de garantir les transitions et les changements d'état". See also Lévêque; Verbanck-Piérard in Bonnet; Jourdain-Annequin (1992: 43-65, particularly 47): “Le héros mycénien s'est donc parfaitement adapté à la cité et à l'expansion coloniale, et, mieux encore, il s'est montré un adjuvant remarquable de ces mouvements de fond de la société archaïque". Philips (1978) interprets Herodotus's references to Heracles in this passage as confirmation of the influence of Egyptian conceptions on the hero's legend without considering, however, his distinctive perspective on the hero in general (comparable in this respect to that of Farnell, 1921: 98). I sum up here Philips's (1978: 431-434) interpretation; he follows grosso modo Farnell (1921: 97-103) and Cook (1906: 365-378). This diachronic explanation is hardly capable of proof, though, and, furthermore, it must be keep in mind that the hero's name is undoubtedly posterior to many important elements of his myth, as stressed by Burkert (1979: 78-98). Although his and Verbanck-Piérard's (1989) interpretations differ in some respects, Philips (1978: 433 and 440) argues similarly that Heracles had always been a mortal hero, so that the Olympian Heracles represented a completely new religious movement that may have garnered legitimacy from its use of a very old title. Philips and Verbanck-Piérard also agree in dating the hero's divinization to the $6^{\text {th }}$ century BCE (Philips, 1978: 439-440), while Farnell (1921: 97-103) and Kirk (1974: 179) date it to the $7^{\text {th }}$. Lévêque \& Verbanck-Piérard in Bonnet \& Jourdain-Annequin (1992: 48-49) suggest that Heracles originated as the third character of a sacred family of the neolithic type in association Hera and Athena as mother-goddess and daughter-goddess. For Baurain (in Bonnet \& Jourdain-Annequin, 1992: 104, with notes 143 and 144), Heracles's two-fold nature reflects the belending of the epic Heracles with the Cretan Idean Heracles, the Phoenician-Cypriot Bes, and the Tyrian Melqart.

51 Verbanck-Piérard (1989: 194): "La mention d'Héraklès-dieu s'exprime d'abord par un passage horizontal, par une intégration sans obstacle et sans rupture à la sphère olympienne. Il est fondamental de noter que, pour les peintres du VI ${ }^{\grave{e}}$ siècle, Héraklès ne connaît pas la mort et n'utilise aucun talisman pour accéder à l'Olympe (...). Malgré le rôle indispensable d'Athéna et d'Hermès, c'est en fonction de la relation Héraklès / Zeus que doivent être comprises les premières créations". It is certainly not without importance to remind that Heracles' relation to his father is comparable to Apollo's, particularly in that god's first arrival on Olympos as described at the beginning of the Homeric Hymn.

52 Verbanck-Piérard (1984: 194): "Dans le culte, l'association Héraklès / Athéna semble inexistente. Par contre, elle est un terme indispensable du langage iconographique. (...) Par ses gestes et son maintien, Athéna reconnaît Héraklès comme un pair et lui assure la bénédiction des autres dieux. L'idée d'un échange, d'une complémentarité, d'une équivalence entre les deux divinités s'intensifie progressivement au cours du VI ${ }^{\grave{e}}$ siècle et aboutit à des représentations presque ambigües du couple Héraklès-Athéna”. Schauenburg (1963: 115-117) notes that the motif of representing Heracles next to Athena and going with her to the Olympus vanished almost completely from the artists' repertoire as early as the end of the Archaic period, also disappearing from Greek pottery outside Attica in south Italy. From the $4^{\text {th }}$ century BCE on, the increasingly prevailing motif across Greece is the quadriga journey. In Red Figure pottery, as opposed to Black Figure, the car is usually being drawn through the air or over the sea and sometimes; in other cases, it is stationary next to the hero.

53 Schauenburg (1963: 127-129).

54 Schauenburg (1963: 130-131) criticizes as excessive the number of vase paintings categorized as 'Heracles's apotheosis' by P. Mingazzini, "Le rappresentazioni vascolari del mito dell'apoteosi di Herakles”, Memoria de l'Academia dei Lincei 6, Serie I, 1925, and by P. Metzger, Les représentations dans la céramique attique du $4^{\dot{e} m e}$ siècle, 1951, though these remain 
important works in the bibliography on the subject. Schauenbrug's criticism focuses on the interpretation of specific groupings of figures; for him, Dionysos's mere presence is insufficient to indicate reference the hero's divinization, while some vases depend on the satyr plays; he also urges greater attention to scenes in which he rests after completing his labors (1963: 117-126). The vase paintings in which Heracles is crowned by Victory, appears by her side, or wears a band representing her are more difficult to judge. In any case, considering that these representations belong to his victory cycle, there is no reason to consider them to be set elsewhere than on earth (op. cit.: 122-126). Similarly difficult to interpret are scenes on Italic vases that depict groups of gods from which Zeus is absent, though these too probably have a terrestrial rather than Olympian setting (op. cit.: 128).

55 I would like to thank the editor of Synthesis, Graciela C. Zecchin de Fasano, for the generous offer and the intellectual encouragement to publish this paper, without which it would not have come to light. My sincere thanks also go to Jim Marks for help with the English in this paper as well as many valuable observations concerning Greek language and ancient poetry and culture in general. 